\title{
Propagasi in vitro tanaman kurma (Phoenix dactylifera L.) pada bioreaktor dengan perendaman sesaat
}

\author{
In vitro propagation of date palm (Phoenix dactylifera L.) in temporary immersion bioreactor \\ Rizka Tamania SAPTARI*), Masna Maya SINTA, Imron RIYADI, PRIYONO, \& SUMARYONO \\ Pusat Penelitian Bioteknologi dan Bioindustri Indonesia, Jl. Taman Kencana No. 1 Bogor, Indonesia 16128
}

Diterima tgl 16 Agustus 2020 / disetujui tgl 19 Oktober 2020

\begin{abstract}
The cultivation of date palm in Indonesia has increased since the last decade. However, the superior date palm seedlings are still limited and most of them are imported from other countries. The mass supply of superior date palm seedlings can be provided by in vitro propagation in the bioreactor. Therefore, the research was conducted to develop a protocol of date palm in vitro propagation by Temporary Immersion Bioreactor (TIB). The in vitro propagation was carried out through somatic embryogenesis technique using meristematic tissues isolated from offshoots of date palm female clone $\mathrm{cv}$. Zambli as explants. The explants were sterilized and then cultured to produce embryogenic calli and somatic embryos. Afterwards, somatic embryos germination and plantlets formation were conducted in TIB with treatments of immersion period: 3, 10, and 30 minutes every 6 hours, with 8 replications, The results showed that the optimal somatic embryo germination in TIB was with the immersion period of 30 min every $6 \mathrm{~h}$, resulting in the most formation of shoots and fresh biomass weight increment up to nearly threefold in 6 weeks. Thereafter, plantlets formation in TIB with immersion period of $10 \mathrm{~min}$ and 30 min every $6 \quad h$ exhibited similar performances in producing more plantlets with higher total fresh weight and better vigor than those of 3 min every $6 \mathrm{~h}$. However, there were more rooted plantlets in the TIB with immersion period of 10 min every $6 \mathrm{~h}$. Based on the results, an in vitro propagation protocol via somatic embryogenesis in TIB has been successfully developed for mass propagation of date palm $\mathrm{cv}$. Zambli, which produced plantlets with good vigor and rooting.
\end{abstract}

[Keywords: somatic embryogenesis, cv. Zambli, immersion period, TIB]

\begin{abstract}
Abstrak
Budidaya tanaman kurma mulai berkembang di Indonesia sejak satu dekade terakhir. Akan tetapi, benih kurma unggul masih terbatas dan sebagian besar diimpor dari negara lain. Penyediaan benih klonal kurma unggul secara massal dapat dihasilkan melalui propagasi in vitro pada bioreaktor. Oleh karena itu, penelitian ini bertujuan mengembangkan protokol propagasi in vitro kurma menggunakan bioreaktor dengan perendaman sesaat atau Temporary Immersion Bioreactor (TIB). Propagasi in vitro dilakukan melalui teknik embriogenesis somatik menggunakan eksplan jaringan meristematik dari anakan tanaman kurma klonal betina kultivar Zambli. Eksplan tersebut disterilisasi dan dikultur hingga menghasilkan kalus embriogenik dan embrio somatik. Selanjutnya perkecambahan embrio somatik dan pembentukan planlet dilakukan pada TIB dengan perlakuan periode perendaman yaitu 3, 10, dan 30 menit dengan interval perendaman setiap 6 jam, dengan 8 ulangan. Hasil penelitian menunjukkan bahwa perkecambahan embrio somatik pada TIB paling baik dengan periode perendaman 30 menit setiap 6 jam yang menghasilkan tunas terbanyak dan penambahan bobot segar biomassa hampir tiga kali lipat dalam waktu 6 minggu. Selanjutnya, pembentukan planlet pada TIB dengan periode perendaman 10 menit dan 30 menit setiap 6 jam memiliki performa yang sama dalam menghasilkan jumlah planlet dan bobot total planlet lebih tinggi serta vigor planlet lebih baik dibandingkan periode perendaman 3 menit setiap 6 jam, tetapi planlet berakar lebih banyak terbentuk pada TIB dengan periode perendaman 10 menit setiap 6 jam. Berdasarkan hasil penelitian, protokol propagasi in vitro melalui embriogenesis somatik pada TIB berhasil dikembangkan untuk propagasi massal kurma kultivar Zambli yang menghasilkan planlet dengan keragaan dan perakaran yang baik.
\end{abstract}

[Kata kunci: embriogenesis somatik, kultivar Zambli, periode perendaman, TIB] 


\section{Pendahuluan}

Tanaman kurma (Phoenix dactylifera L.) memiliki nilai ekonomi strategis di Indonesia. Konsumsi buah kurma di Indonesia cukup tinggi, dan selalu meningkat pada bulan Ramadhan, mengingat Indonesia merupakan salah satu negara dengan penduduk Muslim terbesar di dunia. Berdasarkan data Badan Pusat Statistik (BPS, 2020), buah kurma menjadi salah satu dari sepuluh barang konsumsi yang mengalami peningkatan impor tertinggi. Akumulasi impor buah kurma selama tahun 2019 mencapai 36,2 juta kilogram senilai US\$ 62,29 juta (BPS, 2020).

Tingginya konsumsi buah kurma menyebabkan budidaya kurma tropis di Indonesia mulai diminati sejak satu dekade terakhir (Rahmadani et al., 2017). Pengusaha kurma berharap Indonesia dapat menjadi negara penghasil buah kurma tropis di masa depan, selain Thailand yang telah menjadi pelopor budidaya kurma tropis di Asia Tenggara (Apriyanti et al., 2016). Kurma tropis yang dibudidayakan di Thailand adalah KL-1 hasil pemuliaan dari induk kultivar Degleet Nour dan Barhee yang dilakukan oleh periset di Maejo University (Apriyanti et al., 2016), sedangkan di Indonesia, kebun kurma seperti di Jonggol Farm Bogor menggunakan benih kultur jaringan yang berasal dari Inggris. Hingga saat ini belum ada laboratorium di Indonesia yang mampu menyediakan benih kultur jaringan kurma skala komersial.

Benih kultur jaringan bersifat klonal atau sama seperti induk sumber tanamannya. Benih kultur jaringan diproduksi melalui propagasi in vitro. Melalui propagasi in vitro dapat tersedia benih klonal kurma skala massal, terutama kurma betina dengan karakter unggul dan sesuai untuk ditanam di wilayah tropis seperti di Indonesia. Propagasi in vitro juga memiliki keunggulan dari segi waktu dan kebutuhan bahan tanam dibandingkan propagasi konvensional. Sebagai contoh, propagasi in vitro kurma menggunakan satu tunas anakan, melalui teknik embriogenesis somatik (somatic embryogenesis, SE) pada kultur suspensi mampu menghasilkan 10.000 embrio somatik per liter per bulan, yang selanjutnya berkembang menjadi planlet dan diaklimatisasi menjadi benih dengan daya hidup 70\% (Fki et al., 2011a).

Propagasi in vitro skala massal memerlukan sistem yang efisien, salah satunya dengan penggunaan bioreaktor (Othmani et al., 2017). Pemanfaatan bioreaktor pada awalnya adalah untuk kultivasi mikroba. Kemudian dengan semakin berkembangnya teknik kultur sel tanaman, maka bioreaktor digunakan juga untuk produksi metabolit sekunder dari sel tanaman, yang kemudian berkembang untuk propagasi tanaman dalam skala besar (Vidal \& Sánchez, 2019). Penggunaan bioreaktor memungkinkan otomatisasi dalam prosedur propagasi tanaman juga menghemat biaya produksi (Georgiev et al., 2014).
Salah satu jenis bioreaktor yang banyak digunakan untuk tujuan propagasi tanaman yaitu bioreaktor dengan perendaman sesaat, atau Temporary Immersion Bioreactor (TIB) (Vidal \& Sánchez, 2019). TIB terdiri dari tiga komponen utama, yaitu bejana beserta selang penghubung, mesin pewaktu (timer), dan pompa. Bejana bioreaktor dihubungkan pada mesin pewaktu yang mengatur durasi dan interval media cair untuk kontak dengan propagul tanaman (Georgiev et al., 2014).

Sesuai namanya, perendaman sesaat, sistem ini memungkinkan propagul tanaman pada bioreaktor untuk kontak dengan media cair hanya pada waktu tertentu secara periodik. Sistem ini dianggap paling sesuai untuk propagasi tanaman karena menghindarkan propagul tanaman terus menerus kontak dengan media cair yang mengakibatkan hambatan pertumbuhan. Keunggulan lainnya yaitu sistem ini dapat menjaga ketersediaan nutrisi dan oksigen yang seimbang bagi tanaman di dalam bioreaktor tanpa menggunakan agitasi yang menyebabkan kerusakan pada propagul tanaman (Watt, 2012). Oleh karena itu, pengaturan periode perendaman pada TIB menjadi faktor penting untuk menciptakan keseimbangan nutrisi dan oksigen yang optimal bagi tanaman yang dipropagasi.

Beberapa penelitian tentang keberhasilan propagasi in vitro tanaman kurma menggunakan TIB telah dilaporkan, antara lain untuk kultivar Deglet Bey (Othmani et al., 2009), Barhee (Fki et al., 2011b), Quntar (Al-Mayahi, 2015), serta Mejhool dan Boufeggous (Abahmane, 2020). Keberhasilan propagasi in vitro kurma di Indonesia telah dilaporkan oleh Saptari \& Sumaryono (2018), yang dilakukan melalui embriogenesis somatik, namun menggunakan eksplan berupa tanaman muda dari biji yang belum dapat ditentukan apakah akan menghasilkan tanaman jantan atau betina, serta menggunakan sistem kultur padat. Oleh karena itu, penelitian ini dilakukan untuk mengembangkan protokol propagasi in vitro kurma pada TIB agar dapat dilakukan produksi massal benih kultur jaringan kurma unggul di Indonesia dari sumber tanaman klonal yang telah diketahui jenisnya (jantan atau betina) dan telah adaptif di Indonesia.

Tanaman yang digunakan sebagai sumber eksplan merupakan tanaman klonal kultivar Zambli hasil kultur jaringan yang telah ditanam Jonggol Farm, Jawa Barat, dan sudah pernah berbunga, sehingga dianggap telah adaptif di Indonesia. Kurma kultivar Zambli merupakan salah satu kurma betina unggul yang menghasilkan buah besar dan hasil panen buah tinggi, yaitu 60$80 \mathrm{~kg}$ per tahun, serta mudah dalam penyerbukan (Gurra-Downs, 2019). Oleh karena itu, pengembangan protokol propagasi in vitro kurma kultivar Zambli ini merupakan upaya untuk mendukung penyediaan bahan tanam kurma betina 
unggul yang diharapkan dapat berproduksi dengan baik di Indonesia.

\section{Bahan dan Metode}

\section{Pengambilan bahan tanaman dan isolasi eksplan}

Tanaman yang digunakan sebagai sumber eksplan merupakan tanaman kurma klonal betina dari kultivar Zambli berumur 3 tahun, yang ditanam di Jonggol Farm, Bogor, Jawa Barat. Anakan (offshoots) dari tanaman tersebut diisolasi dan dibawa ke laboratorium. Pelepah-pelepah terluar dari anakan dikupas secara berurutan berdasarkan filotaksis, kemudian bagian pucuk tanpa pelepah berukuran panjang $\pm 12,5 \mathrm{~cm}$ dan diameter $\pm 4,5 \mathrm{~cm}$ dibersihkan dengan sabun dan dicuci dengan air mengalir. Selanjutnya, eksplan dibawa ke dalam Laminar Air Flow (LAF) cabinet untuk proses sterilisasi. Sterilisasi dilakukan menggunakan larutan Benomyl 0,5\% dan $\mathrm{NaOCl}$ $20 \%$ selama 30 menit, kemudian dibilas dengan akuades steril sebanyak tiga kali. Eksplan dikering-anginkan. Jaringan meristematik diisolasi dengan cara mengupas primordia daun terluar hingga diperoleh sekitar 4 lapisan primordia terdalam dan jaringan meristem apikal yang kemudian dipotong-potong dengan ukuran $1 \mathrm{~cm} \mathrm{x}$ $1 \mathrm{~cm}$ untuk digunakan sebagai inisiasi kalus embriogenik.

\section{Inisiasi kalus embriogenik}

Media untuk inisiasi kalus terdiri dari basal mineral berdasarkan Al-Khayri (2018), ditambahkan asam 2,4- diklorofenoksi asetat (2,4D) dengan konsentrasi 452,2 $\mu \mathrm{M}$ dan 2isopenteniladenina (2-iP) dengan konsentrasi 14,7 $\mu \mathrm{M}$, sukrosa $40 \mathrm{~g} \mathrm{~L}^{-1}$, arang aktif $1,5 \mathrm{~g} \mathrm{~L}^{-1}$, dan gelzan $3,5 \quad \mathrm{~g} \mathrm{~L}^{-1}$ sebagai pemadat. Derajat keasaman $(\mathrm{pH})$ media diatur sebesar 5,7, kemudian media dituangkan pada botol-botol jar. Setiap botol jar berisi $30 \mathrm{~mL}$ media disterilisasi menggunakan otoklaf dengan suhu $121{ }^{\circ} \mathrm{C}$, tekanan $1 \mathrm{~kg} \mathrm{~cm}^{-2}$, selama 15 menit. Media yang telah steril didiamkan selama 24 jam sebelum digunakan. Setelah itu, pada setiap botol jar berisi media inisiasi, diinokulasikan masing-masing 4 potongan eksplan. Selanjutnya botol jar ditutup dan diberi segel plastik, kemudian diinkubasi pada ruang kultur dengan suhu $25 \pm 2{ }^{\circ} \mathrm{C}$ dan tanpa pencahayaan, hingga terbentuk kalus embriogenik.

\section{Induksi embrio somatik pada kultur cair}

Tahap selanjutnya dari propagasi in vitro kurma melalui teknik SE adalah menginduksi embrio somatik dari kalus embriogenik. Media yang digunakan untuk induksi embrio somatik berupa media cair dengan komposisi yang sama dengan media inisiasi kalus, namun tanpa penggunaan zat pengatur tumbuh, dan disterilkan seperti pembuatan media induksi kalus. Induksi embrio somatik dilakukan menggunakan dua sistem kultur cair, yaitu kultur suspensi pada labu Erlenmeyer $100 \mathrm{~mL}$ dan kultur perendaman sesaat pada TIB. Pada kultur suspensi, sebanyak 0,5 g kalus embriogenik diinokulasikan ke dalam $25 \mathrm{~mL}$ media cair dalam labu Erlenmeyer $100 \mathrm{~mL}$. Kemudian labu-labu Erlenmeyer berisi kalus embriogenik diletakkan pada rotary shaker dengan kecepatan rotasi $90 \mathrm{rpm}$. Untuk kultur perendaman sesaat pada TIB, sebanyak $0,5 \mathrm{~g}$ kalus embriogenik diinokulasikan ke dalam bejana TIB yang berisi $175 \mathrm{~mL}$ media cair. Selanjutnya, bejana-bejana TIB tersebut dihubungkan pada sistem pengaturan perendaman periodik secara otomatis, yaitu periode (durasi) perendaman selama 3 menit dengan interval perendaman setiap 6 jam berdasarkan Sumaryono et al. (2008). Inkubasi kultur dilakukan selama 6 minggu di dalam ruangan dengan suhu $25 \pm 2{ }^{\circ} \mathrm{C}$ dan pencahayaan lampu TL LED dengan fotoperiode $12 \mathrm{jam}$. Setelah 6 minggu, dihitung jumlah embrio somatik yang terbentuk dan ditimbang bobot segar akhir. Setiap sistem kultur cair memiliki 6 kali ulangan. Perbedaan antara dua sistem kultur cair dianalisis secara statistik menggunakan uji-T dengan taraf kepercayaan $95 \%$.

\section{Perkecambahan embrio somatik pada TIB}

Perkecambahan embrio somatik kurma dilakukan pada sistem TIB, menggunakan media cair dengan komposisi yang sama dengan media induksi embrio somatik. Media disterilkan seperti pembuatan media sebelumnya (Al-Khayri, 2018). Selanjutnya, sebanyak $175 \mathrm{~mL}$ media steril dituangkan pada bejana TIB di dalam LAF. Kemudian eksplan berupa embrio somatik fase lanjut yang sudah nampak akan tumbuh koleoptilnya dari kultur TIB, masing-masing sebanyak $10 \mathrm{~g}$ diinokulasikan pada bejana TIB. Bejana TIB ditutup dan diberi segel plastik, kemudian dihubungkan pada sistem untuk mengatur periode dan interval perendaman kultur. Pada penelitian ini digunakan tiga perlakuan periode perendaman, yaitu 3 , 10, dan 30 menit dengan interval perendaman setiap 6 jam. Setiap perlakuan memiliki delapan ulangan. Sistem TIB ditempatkan pada ruang kultur dengan suhu $25 \pm 2{ }^{\circ} \mathrm{C}$ dan pencahayaan lampu TL LED dengan fotoperiode $12 \mathrm{jam}$. Setelah empat minggu, diamati hasil perkecambahan embrio somatik pada TIB yang meliputi jumlah dan bobot segar tunas yang terbentuk, serta bobot embrio somatik yang belum berkecambah. Data yang diperoleh dianalisis dengan analisis sidik ragam dan dilanjutkan dengan uji Tukey pada taraf kepercayaan $95 \%$.

\section{Pembentukan planlet pada TIB}

Pembentukan planlet dilakukan menggunakan sistem TIB, dengan komposisi media yang sama dengan tahap induksi dan perkecambahan embrio somatik. Masing-masing sebanyak 15 tunas kurma 
dengan ukuran 2-3 cm (rerata bobot segar awal 6 g) yang dihasilkan dari tahap sebelumnya diinokulasikan pada bejana TIB berisi $175 \mathrm{~mL}$ media cair. Bejana TIB ditutup dan diberi segel plastik, kemudian dihubungkan pada sistem untuk mengatur periode perendaman kultur. Pada penelitian ini digunakan tiga perlakuan periode perendaman, yaitu 3, 10, dan 30 menit setiap 6 jam. Setiap perlakuan memiliki delapan ulangan. Sistem TIB ditempatkan pada ruang kultur dengan suhu $25 \pm 2{ }^{\circ} \mathrm{C}$ dan pencahayaan lampu TL LED dengan fotoperiode 12 jam. Setelah 8 minggu, diamati pembentukan planlet pada TIB yang meliputi jumlah dan bobot segar planlet yang terbentuk, serta bobot tunas yang belum menjadi planlet setelah inkubasi. Data yang diperoleh dianalisis dengan analisis sidik ragam dan dilanjutkan dengan uji Tukey pada taraf kepercayaan $95 \%$.

\section{Hasil dan Pembahasan}

\section{Inisiasi kalus embriogenik kurma}

Inisiasi kultur kurma berhasil dilakukan dengan tingkat kontaminasi rendah, yaitu 3,5\%. Perkembangan eksplan cukup lambat. Setelah 5 minggu inkubasi, ukuran eksplan membesar sehingga perlu dilakukan subkultur ke medium baru dengan komposisi yang sama. Kemudian kalus awal kurma atau kalus primer terbentuk setelah 19 minggu inkubasi dengan persentase $18,2 \%$. Kalus primer memiliki struktur basah dengan warna putih translusen (Gambar 1a). Kalus tersebut terus diproliferasi hingga diperoleh kalus embriogenik seperti pada Gambar 1b. Tahap induksi hingga memperoleh kalus embriogenik kurma relatif lama, yaitu $8-9$ bulan. Hasil penelitian pada kultivar kurma lainnya dari eksplan yang sama juga menunjukkan periode pembentukan kalus embriogenik yang lama, antara lain 8 bulan pada kultivar Deglet Bey (Othmani et al., 2009) dan 9 bulan pada kultivar Zaghlol, Amry, dan Malakaby (Hassan \& Taha, 2012).

Keberhasilan pembentukan kalus embriogenik cukup tinggi, yaitu 79,6\%. Kalus embriogenik kurma memiliki struktur noduler yang remah, kering, dan berwarna putih doff (Gambar 1b). Aslam et al. (2011) melaporkan hasil analisis histologi kalus embriogenik beberapa kultivar kurma memiliki bentuk sel bulat kompak berukuran kecil-kecil dengan sitoplasma dan nukleus yang padat, serupa dengan morfologi kalus embriogenik yang diperoleh pada penelitian ini (Gambar 1b). Morfologi kalus embriogenik dan non-embriogenik yang diperoleh pada penelitian ini juga serupa seperti yang dilaporkan Silveira $e t$ al. (2013) pada embriogenesis somatik tanaman tebu, yang menunjukkan kalus embriogenik berupa sel yang kompak, isodiametrik, dan mudah dibedakan dengan kalus lainnya, sedangkan kalus non-embriogenik berstruktur lunak dan berwarna translusen. Menurut Heringer et al. (2015) dan
Oliveira et al. (2017), kalus embriogenik memiliki warna lebih pekat atau doff, dan tidak translusen seperti pada kalus non-embriogenik karena sel-sel kalus embriogenik mengandung akumulasi protein dan karbohidrat yang lebih tinggi dibandingkan kalus non-embriogenik. Secara fungsional, Passamani et al. (2018) dan Parrilla et al. (2018) menjelaskan bahwa kalus embriogenik memiliki aktivitas metabolisme yang tinggi, seperti pertukaran ion $\mathrm{H}^{+}$sel, tahap awal glikolisis, fosforilasi oksidatif, sehingga memiliki kapasitas regenerasi embrio somatik yang tinggi apabila diinduksi melalui embriogenesis somatik. Maka pada penelitian ini, selanjutnya kalus embriogenik yang diperoleh digunakan sebagai bahan propagasi massal kurma klonal melalui embriogenesis somatik, yang meliputi tahap induksi embrio somatik, perkecambahan embrio somatik, dan pembentukan planlet.

\section{Induksi embrio somatik kurma pada kultur suspensi dan TIB}

Hasil induksi embrio somatik pada dua jenis sistem kultur cair menunjukkan bahwa laju proliferasi kalus embriogenik tidak berbeda nyata antara kultur suspensi dengan kultur TIB (Gambar 2a), akan tetapi jumlah embrio somatik yang terbentuk lebih banyak pada kultur TIB (Gambar 2b). Kedua sistem kultur cair, yaitu kultur suspensi dan TIB memiliki perbedaan volume bejana yang digunakan, dengan keuntungannya masingmasing. Kultur TIB memiliki keunggulan bejana TIB yang lebih besar yang menyediakan ruang tumbuh tanaman yang lebih luas untuk dapat tumbuh dan bermultiplikasi optimal, sedangkan kultur suspensi menggunakan bejana Erlenmeyer dengan volume yang lebih kecil dari bejana TIB dapat mencegah kerugian besar apabila terjadi kontaminasi hanya pada satu bejana. Hasil penelitian ini yang menunjukkan kultur TIB lebih baik dalam pembentukan embrio somatik kurma serupa dengan penelitian Alvard et al. (1993) yang membandingkan beberapa sistem kultur pada mikropropagasi tanaman pisang dan hasilnya menunjukkan bahwa penggunaan sistem TIB menghasilkan laju proliferasi tunas tertinggi

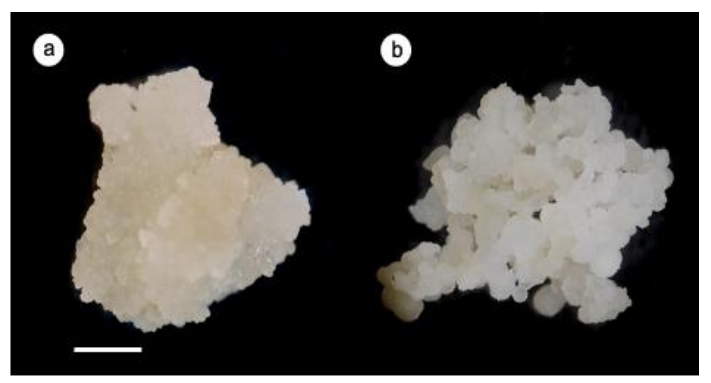

Gambar 1. Kalus primer (a) dan kalus embriogenik (b) kurma kultivar Zambli. Skala garis $=1 \mathrm{~mm}$

Figure 1. Primary calli (a) and embryogenic calli (b) date palm cv. Zambli. Bar scale $=1 \mathrm{~mm}$ 
a.

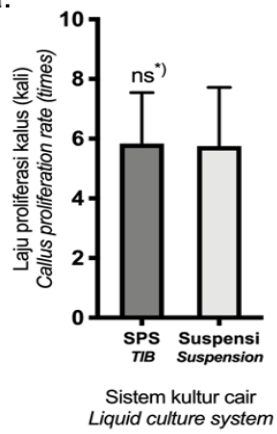

b.

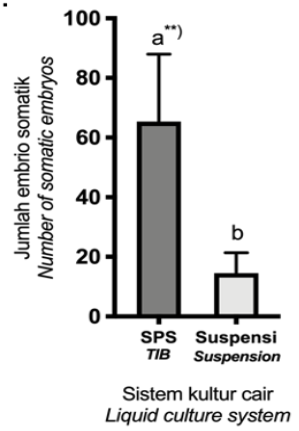

Gambar 2. Laju proliferasi kalus (a) dan jumlah embrio somatik (b) yang terbentuk dari kultur TIB dan suspensi kurma klon Zambli setelah inkubasi selama 6 minggu

$\left.{ }^{*}\right)$ nilai rerata tidak berbeda nyata berdasarkan uji-T pada tingkat kepercayaan $95 \%$

**) nilai rerata berbeda nyata berdasarkan uji-T pada tingkat kepercayaan $95 \%$

Figure 2. Callus proliferation rate (a) and number of somatic embryos (b) from TIB and suspension culture of date palm clone Zambli after 6 weeks of incubation

") means are not significantly different according to T-test at $95 \%$ confidence level

${ }^{* *}$ means are significantly different according to T-test at $95 \%$ confidence level

dibandingkan kultur padat, kultur cair suspensi, kultur cair dengan filter selulosa, dan kultur cair dengan aerasi gelembung udara.

Sumaryono et al. (2008) juga melaporkan bahwa penggunaan kultur TIB menghasilkan pertumbuhan kalus yang lebih baik pada embriogenesis somatik tanaman sagu, dibandingkan kultur padat dan kultur suspensi. Menurut Ascough \& Fennell (2004), salah satu penyebab TIB unggul dalam meningkatkan regenerasi tanaman dibandingkan kultur suspensi adalah rendahnya shear stress karena tidak perlu digoyang menggunakan shaker seperti yang terjadi pada kultur suspensi. Berdasarkan hasil tersebut, maka tahap regenerasi kurma selanjutnya dilakukan pada TIB.

\section{Perkecambahan embrio somatik dan pembentukan planlet kurma pada TIB}

Embrio somatik pada fase lanjut (Gambar 3) mampu berkecambah pada TIB setelah empat minggu. Berdasarkan Tabel 1 dan Gambar 4, perkecambahan embrio somatik kurma pada TIB optimal pada periode perendaman 30 menit setiap 6 jam. Perlakuan ini menghasilkan tunas paling banyak, yaitu rata-rata 25,2 tunas setiap bejana TIB, berbeda nyata dibandingkan perlakuan lainnya. Selain itu, perlakuan ini juga menghasilkan rerata bobot segar tertinggi, baik bobot segar tunas $(11,18 \mathrm{~g})$ maupun bobot segar embrio yang belum berkecambah $(29,21 \mathrm{~g})$. Bobot segar tunas dari perlakuan periode perendaman 30 menit setiap 6 jam berbeda nyata dibandingkan perlakuan lainnya, sedangkan bobot segar embrio yang belum berkecambah berbeda nyata dibandingkan dengan periode perendaman 3 menit setiap 6 jam. Penambahan bobot segar total pada perlakuan periode perendaman 30 menit setiap 6 jam mencapai $297,8 \%$ dalam waktu 4 minggu, berbeda nyata dibandingkan perlakuan lainnya.
Hasil yang diperoleh pada penelitian ini berbeda dengan hasil penelitian Othmani et al. (2009) pada kultivar Deglet Bey, yang menunjukkan pembentukan tunas kurma terbaik pada TIB dengan periode perendaman 3 menit setiap 8 jam, sedangkan penambahan waktu perendaman menjadi 5 menit dan 7 menit justru menyebabkan penurunan jumlah tunas terbentuk. Hal ini menunjukkan bahwa periode perendaman merupakan faktor terpenting yang mempengaruhi pertumbuhan tanaman pada TIB. Periode perendaman yang optimal bergantung pada jenis tanaman (spesies dan genetik tanaman), jenis eksplan, juga tahap atau fase pertumbuhan tanaman, seperti yang dipaparkan oleh Watt (2012) mengenai berbagai perlakuan periode perendaman spesifik yang pernah diteliti untuk beragam spesies tanaman, jenis dan tahap pertumbuhan eksplan.

Berbeda dengan tahap perkecambahan embrio somatik, pada tahap pembentukan planlet dalam TIB, periode perendaman 10 menit dan 30 menit setiap 6 jam menghasilkan jumlah planlet yang tidak berbeda nyata (Tabel 2). Kedua perlakuan tersebut menghasilkan planlet lebih banyak dibandingkan periode perendaman 3 menit yang hanya menghasilkan rata-rata 6,7 planlet pada setiap bejana TIB. Pada pengamatan ini, yang disebut sebagai planlet adalah yang telah memiliki helai daun yang membuka sempurna dengan panjang minimal $4 \mathrm{~cm}$, baik telah memiliki akar maupun yang belum berakar (Gambar 5). Karakteristik pertumbuhan planlet pada periode perendaman 3 menit setiap 6 jam cenderung menghasilkan planlet yang tinggi (rata-rata 7,9 cm) dengan daun yang panjang, namun lebar daunnya sempit (rata-rata 0,31 cm). Sebaliknya, pada perlakuan periode perendaman 10 menit dan $\quad 30$ menit setiap 6 jam cenderung menghasilkan planlet dengan keragaan yang lebih baik, yaitu planlet lebih pendek dibandingkan periode perendaman 3 menit (rata-rata $6,2 \mathrm{~cm}$ dan $7,0 \mathrm{~cm}$, berturut-turut), 
Tabel 1. Perkecambahan embrio somatik kurma pada TIB setelah 4 minggu inkubasi Table 1. Germination of date palm somatic embryos in TIB after 4 weeks of incubation

\begin{tabular}{|c|c|c|c|c|c|}
\hline $\begin{array}{c}\text { Durasi perendaman } \\
\text { setiap interval } 6 \text { jam } \\
\text { Immersion duration } \\
\text { every } 6 \text { hours } \\
\text { interval }\end{array}$ & $\begin{array}{c}\text { Jumlah } \\
\text { tunas } \\
\text { Number of } \\
\text { shoots }\end{array}$ & $\begin{array}{l}\text { Total penambahan } \\
\text { bobot segar }(\mathrm{g}) \\
\text { Total fresh weight } \\
\text { increment }(g)\end{array}$ & $\begin{array}{c}\text { Persentase } \\
\text { penambahan } \\
\text { bobot segar }(\%) \\
\text { Percentage of } \\
\text { total fresh weight } \\
\text { increment }(\%)\end{array}$ & $\begin{array}{c}\text { Bobot segar } \\
\text { embrio belum } \\
\text { berkecambah }(\mathrm{g}) \\
\text { Non-germinated } \\
\text { embryos fresh } \\
\text { weight }(\mathrm{g})\end{array}$ & $\begin{array}{l}\text { Bobot segar } \\
\text { tunas (g) } \\
\text { Shoots fresh } \\
\text { weight }(g)\end{array}$ \\
\hline $\begin{array}{l}3 \text { menit } \\
3 \text { minutes }\end{array}$ & $10,7 \mathbf{c}^{*)}$ & $8,01 \mathbf{c}$ & $77,7 \mathbf{c}$ & $15,25 \mathbf{b}$ & $3,06 \mathbf{c}$ \\
\hline $\begin{array}{l}10 \text { menit } \\
10 \text { minutes }\end{array}$ & $15,2 \mathbf{b}$ & $19,53 \mathbf{b}$ & $197,8 \mathbf{b}$ & $22,90 \mathbf{a b}$ & $6,55 \mathbf{b}$ \\
\hline $\begin{array}{l}30 \text { menit } \\
30 \text { minutes }\end{array}$ & $25,2 \mathbf{a}$ & $30,24 \mathbf{a}$ & $297,8 \mathbf{a}$ & $29,21 \mathbf{a}$ & $11,18 \mathbf{a}$ \\
\hline
\end{tabular}

${ }^{*}$ Huruf yang sama pada kolom yang sama menunjukkan nilai rerata tidak berbeda nyata berdasarkan uji Tukey pada tingkat kepercay aan $95 \%$

${ }^{*}$ Same letter in the same column indicates means are not significantly different according to Tukey's test at 95\% confidence level

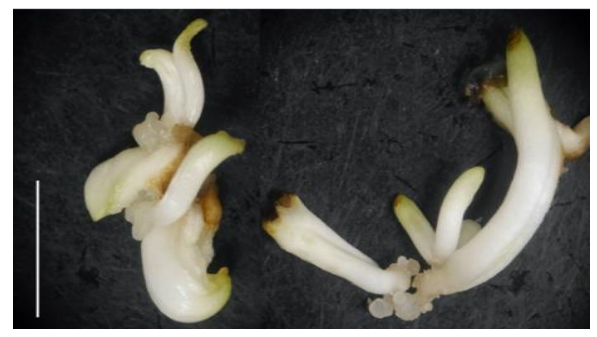

Gambar 3. Embrio somatik kurma fase lanjut yang dikecambahkan pada TIB. Skala garis $=0,5 \mathrm{~cm}$ Figure 3. Advanced phase somatic embryos of date palm germinated in TIB. Bar scale $=0.5 \mathrm{~cm}$

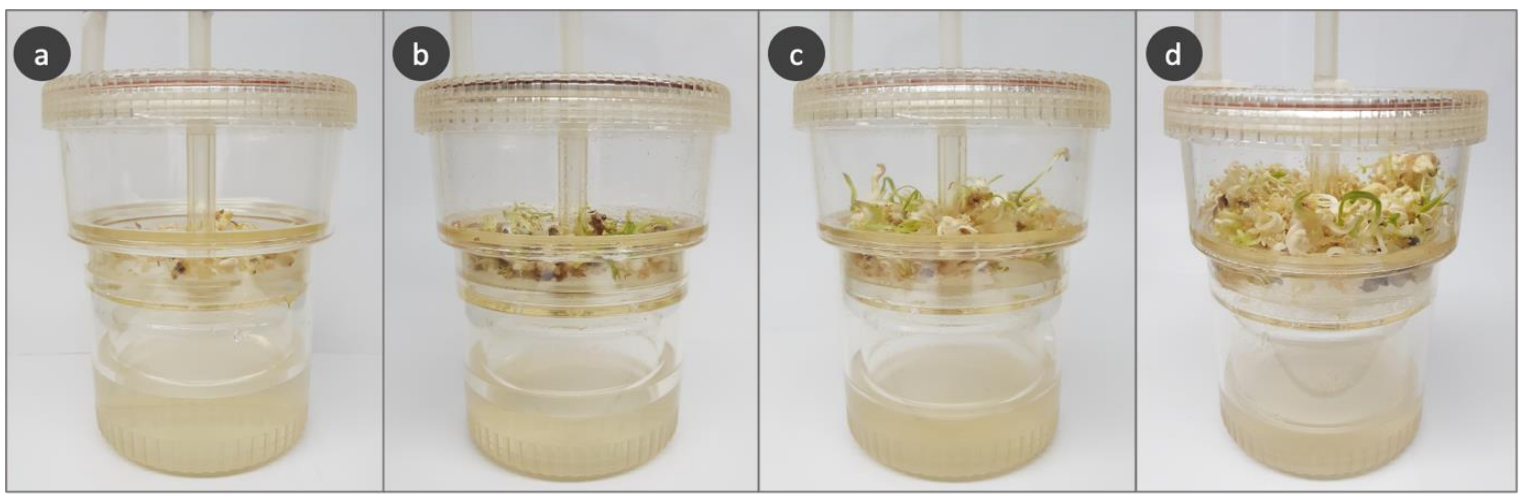

Gambar 4. Perkecambahan embrio somatik kurma pada TIB saat awal inkubasi (a) dan setelah 4 minggu inkubasi dengan periode perendaman 3 menit (b), 10 menit (c), dan 30 menit (d) dengan interval perendaman 6 jam

Figure 4. Germination of date palm somatic embryos in TIB at the beginning of incubation (a) and after 4 weeks of incubation with immersion period of $3 \mathrm{~min}(b), 10 \mathrm{~min}(c)$, and $30 \mathrm{~min}(d)$ with $6 \mathrm{~h}$ immersion interval

namun daunnya lebih lebar (rata-rata $0,59 \mathrm{~cm}$ dan $0,61 \mathrm{~cm}$ berturut-turut) (Tabel $2 \&$ Gambar 5). Planlet yang terbentuk pada perlakuan periode perendaman 10 menit dan 30 menit setiap 6 jam cenderung berupa rumpun sehingga memiliki banyak helai daun. Sebaliknya, pada periode perendaman 3 menit cenderung terbentuk planlet tunggal (Gambar 5).

Perlakuan periode perendaman 10 menit setiap 6 jam memiliki kelebihan dibandingkan perlakuan lainnya, yaitu menghasilkan planlet dengan rerata jumlah helai daun tertinggi ( 8 helai daun per planlet) yang menghasilkan total bobot segar planlet tertinggi, serta menghasilkan lebih banyak planlet berakar (Tabel 2). Apabila perakaran sudah terbentuk pada TIB, teknologi produksi benih bisa menjadi lebih efisien, karena tidak perlu melalui tahap pembentukan akar terlebih dahulu sebelum diadaptasi ke lapangan, mengingat menurut penelitian Othmani et al. (2009), akar sangat jarang 
tumbuh pada planlet kurma yang dikultur dalam TIB. Othmani et al. (2017) melaporkan penelitian kultur kurma cv. Deglet Bey yang hanya menghasilkan persentase pengakaran sebesar $10 \%$ pada TIB dengan periode perendaman 5 menit setiap 8 jam, sedangkan pada penelitian ini menggunakan periode perendaman 10 menit setiap 6 jam menghasilkan persentase pembentukan akar planlet hingga $52,7 \%$.

Hasil pembentukan planlet pada perlakuan ini memiliki potensi keberhasilan aklimatisasi yang lebih baik. Menurut Emoghene et al. (2018), perakaran yang baik menjadi salah satu kunci keberhasilan aklimatisasi benih kultur jaringan. Selain itu, Hassan et al. (2014) mensyaratkan hanya planlet kurma yang telah berakar dengan 3 4 helai daun yang dapat diaklimatisasi, baik dalam bentuk planlet tunggal maupun rumpun planlet. Meskipun demikian, aklimatisasi dalam bentuk rumpun memiliki daya hidup tertinggi dibandingkan dalam bentuk planlet tunggal maupun rumpun yang dipisahkan. Oleh karena itu, pembentukan planlet pada TIB menggunakan periode perendaman 10 menit setiap 6 jam dapat menjadi alternatif yang baik, karena selain menghasilkan jumlah planlet yang banyak, berumpun, dan keragaannya baik, juga lebih banyak planlet yang berakar dibandingkan perlakuan periode perendaman lainnya.

Tabel 2. Pembentukan planlet kurma pada TIB setelah 8 minggu inkubasi

Table 2. Formation of date palm plantlets in TIB after 8 weeks of incubation

\begin{tabular}{|c|c|c|c|c|c|c|}
\hline $\begin{array}{l}\text { Durasi perendaman } \\
\text { setiap interval } \\
6 \text { jam } \\
\text { Immersion duration } \\
\text { every } 6 \text { hours } \\
\text { interval }\end{array}$ & $\begin{array}{l}\text { Jumlah } \\
\text { planlet } \\
\text { Number of } \\
\text { plantlets }\end{array}$ & $\begin{array}{l}\text { Jumlah } \\
\text { planlet } \\
\text { berakar } \\
\text { Number of } \\
\text { rooted } \\
\text { plantlets }\end{array}$ & $\begin{array}{c}\text { Total bobot } \\
\text { segar planlet (g) } \\
\text { Plantlets total } \\
\text { fresh weight } \\
(\mathrm{g})\end{array}$ & $\begin{array}{l}\text { Rerata tinggi } \\
\text { planlet }(\mathrm{cm}) \\
\text { Average of } \\
\text { plantlets } \\
\text { height } \\
(\mathrm{cm})\end{array}$ & $\begin{array}{c}\text { Rerata } \\
\text { jumlah daun } \\
\text { planlet } \\
\text { Average of } \\
\text { plantlets leaf } \\
\text { number }\end{array}$ & $\begin{array}{c}\text { Rerata lebar } \\
\text { daun planlet } \\
(\mathrm{cm}) \\
\text { Average of } \\
\text { plantlets } \\
\text { leaf wide } \\
(\mathrm{cm})\end{array}$ \\
\hline $\begin{array}{l}3 \text { menit } \\
3 \text { minutes }\end{array}$ & $6,7 \mathbf{b}^{*)}$ & $2,3 \mathbf{b}$ & $3,99 \mathbf{c}$ & $7,9 \mathbf{a}$ & $4,1 \mathbf{c}$ & $0,31 \mathbf{b}$ \\
\hline $\begin{array}{l}10 \text { menit } \\
10 \text { minutes }\end{array}$ & $11,0 \mathbf{a}$ & $5,8 \mathbf{a}$ & $8,21 \mathbf{a}$ & $6,2 \mathbf{b}$ & $8,0 \mathbf{a}$ & $0,59 \mathbf{a}$ \\
\hline $\begin{array}{l}30 \text { menit } \\
30 \text { minutes }\end{array}$ & $9,2 \mathbf{a}$ & $3,3 \mathbf{b}$ & $6,72 \mathbf{b}$ & $7,0 \mathbf{b}$ & $6,2 \mathbf{b}$ & $0,61 \mathbf{a}$ \\
\hline
\end{tabular}

*) Huruf yang sama pada kolom yang sama menunjukkan nilai rerata tidak berbeda nyata berdasarkan uji Tukey pada tingkat kepercayaan $95 \%$

*) Same letter in the same column indicates means are not significantly different according to Tukey's test at 95\% confidence level
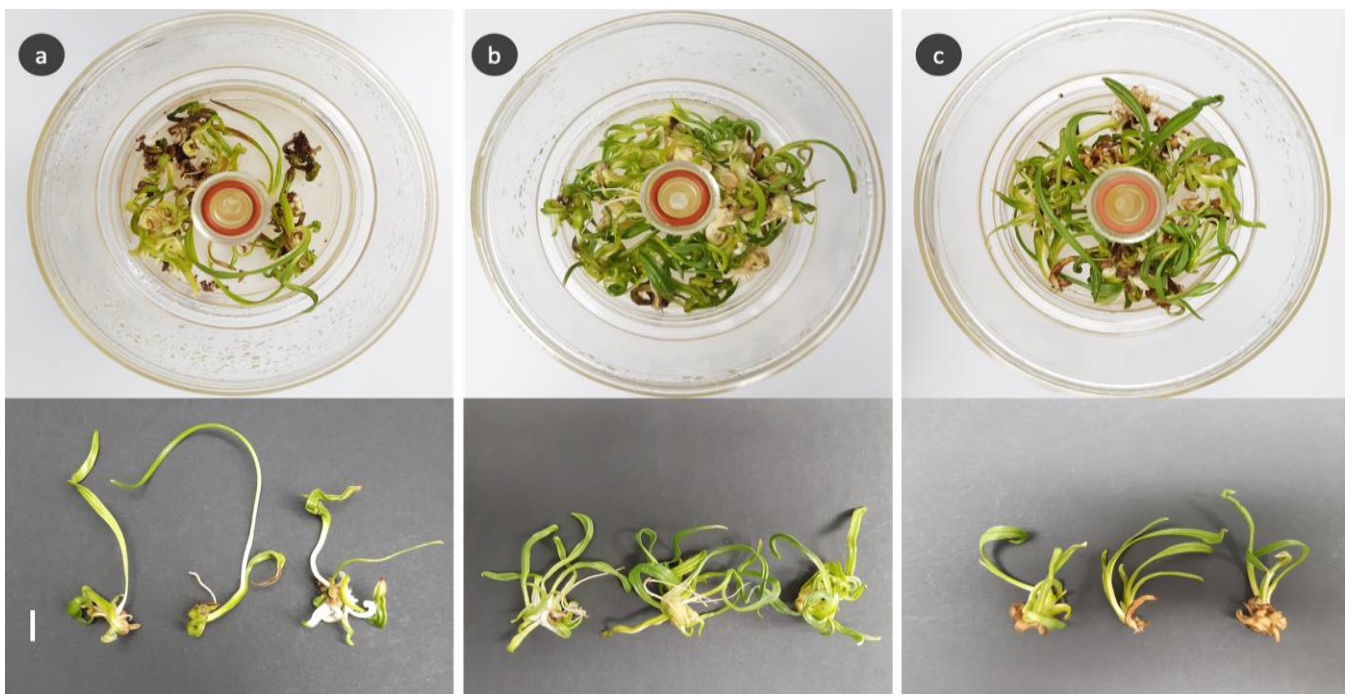

Gambar 5. Pertumbuhan tunas kurma pada TIB setelah 8 minggu inkubasi dengan periode perendaman 3 menit (a), 10 menit (b), dan 30 menit (c) dengan interval 6 jam. Skala garis $=1 \mathrm{~cm}$

Figure 5. Growth of date palm shoots in TIB after 8 weeks of incubation with immersion period of $3 \mathrm{~min}(\mathrm{a}), 10 \mathrm{~min}$ (b), and $30 \mathrm{~min}(\mathrm{c})$ with $6 \mathrm{~h}$ interval. Bar scale $=1 \mathrm{~cm}$ 


\section{Pengaruh periode perendaman terhadap performa setiap tahap embriogenesis somatik kurma}

Hasil penelitian ini menunjukkan bahwa setiap tahap embriogenesis somatik kurma pada TIB, yaitu mulai dari tahap proliferasi kalus, pembentukan embrio somatik, dan perkecambahan embrio somatik memerlukan periode perendaman optimal yang spesifik. Tahap proliferasi kalus dan pembentukan embrio somatik menggunakan periode perendaman 3 menit setiap 6 jam menunjukkan pembentukan embrio somatik yang lebih baik dibandingkan kultur suspensi. Hal ini serupa dengan penelitian SE kurma kultivar Quntar yang juga menggunakan periode perendaman singkat pada tahap pembentukan embrio somatik, yaitu 1 menit setiap 4 jam (Al-Mayahi, 2015). Embrio somatik seringkali terinduksi dengan perlakuan stres (Nic-Can et al., 2016), baik stres osmotikum dengan garam atau gula (Cueva Agila et al., 2015) atau PEG (El Dawayati et al., 2012, Salo et al., 2016), hormon penghambat tumbuh seperti ABA (Salo et al., 2016), maupun stres nutrisi melalui starvasi (Krishnan \& Siril, 2017). Oleh karena itu, periode perendaman yang singkat yaitu 3 menit setiap 6 jam pada tahap pembentukan embrio somatik, memberikan perlakuan stres nutrisi pada kalus embriogenik agar terinduksi menjadi embrio somatik.

Tahap selanjutnya yaitu perkecambahan embrio somatik optimal pada periode perendaman yang lebih lama yaitu $\quad 30$ menit setiap 6 jam dan tahap pembentukan planlet optimal pada periode perendaman 10 menit setiap 6 jam. Pada saat perkecambahan embrio somatik hingga pembentukan planlet, eksplan memerlukan waktu kontak yang lebih lama dengan media, hal ini diduga karena sel tanaman memerlukan energi dan cadangan nutrisi yang lebih banyak untuk memulai proses diferensiasi membentuk tunas, hingga planlet dengan daun dan akar. Berdasarkan hasil penelitian Navarro et al. (2017), pada tahap maturasi embrio somatik Araucaria angustifolia, eksplan mengandung akumulasi gula dan pati yang sangat tinggi yang diperlukan untuk merespons stres maupun sebagai molekul sinyal berbagai proses fisiologis yang terjadi saat maturasi. Eksplan yang rendah cadangan gula dan patinya tidak responsif ke tahap perkembangan berikutnya. Selain itu, Carlsson et al. (2019) melaporkan bahwa pada tahap perkecambahan dan maturasi embrio somatik Picea abies, akumulasi karbon dan nitrogen pada sel tanaman tidak cukup untuk embrio berkecambah sehingga sangat bergantung pada nutrisi dari media maturasi. Pada penelitian ini, energi maupun cadangan karbon dan nitrogen tersebut dapat diperoleh oleh sel-sel embrio somatik kurma dari nutrisi dalam media, yang dapat diserap saat periode perendaman pada TIB. Durasi perendaman yang lebih lama memungkinkan sel-sel embrio somatik mengakumulasi lebih banyak nutrisi yang diperlukan untuk dapat berkecambah hingga membentuk planlet.

\section{Kesimpulan}

Mikropropagasi melalui embriogenesis somatik dengan sistem kultur cair menggunakan TIB berhasil dilakukan pada tanaman kurma $c v$. Zambli, yang menghasilkan planlet kurma dengan keragaan yang baik. Periode perendaman berpengaruh terhadap pertumbuhan tanaman, serta bergantung pada tahap perkembangan tanaman. Periode perendaman terbaik pada tahap proliferasi kalus adalah 3 menit setiap 6 jam, tahap perkecambahan embrio somatik adalah 30 menit setiap 6 jam, sedangkan pada tahap pertumbuhan tunas menjadi planlet adalah 10 menit setiap 6 jam. Perlu penelitian lebih lanjut mengenai kultur in vitro kurma pada TIB dengan lebih banyak variasi durasi dan interval perendaman.

\section{Ucapan Terima Kasih}

Penulis mengucapkan terima kasih kepada pemilik dan manajemen Jonggol Farm, Bogor yang telah menyediakan bahan tanaman kurma berupa anakan.

\section{Daftar Pustaka}

Abahmane L (2020). A comparative study between temporary immersion system and semi-solid cultures on shoot multiplication and plantlets production of two Moroccan date palm (Phoenix dactylifera L.) varieties in vitro. Not Sci Biol 12(2), 277-288.

Al-Khayri JM (2018). Somatic embryogenesis of date palm (Phoenix dactylifera L.) from shoot tip explants. In: Jain SM \& P Gupta (eds.), Step Wise Protocols for Somatic Embryogenesis of Important Woody Plants: Volume II. Cham, Switzerland, Springer International Publishing. p. 231-244.A

Al-Mayahi AMW (2015). An efficient protocol for indirect somatic embryogenesis and shoot organogenesis from leaf segments of date palm (Phoenix dactylifera L.) cv. Quntar. African J Agric Res 10(10), 1031-1042.

Alvard D, F Cote \& C Teisson (1993). Comparison of methods of liquid medium culture for banana micropropagation. Plant Cell Tiss Org Cult 32(1), 55-60.

Apriyanti RN, E Pujiastuti \& DS Rahimah (2016). Kurma dari Gurun ke Tropis. Jakarta, Trubus Swadaya. 224p.

Ascough GD \& CW Fennell (2004). The regulation of plant growth and development in liquid culture. South Afr J Bot 70(2), 181-190. 
Aslam J, SA Khan, AJ Cheruth, A Mujib, MP Sharma \& PS Srivastava (2011). Somatic embryogenesis, scanning electron microscopy, histology and biochemical analysis at different developing stages of embryogenesis in six date palm (Phoenix dactylifera L.) cultivars. Saudi J Biol Sci 18(4), 369-380.

BPS (2020). Impor. In: BPS (eds.), Statistik Perdagangan Luar Negeri. Jakarta, BPS. p. 1177.

Carlsson J, U Egertsdotter, U Ganeteg \& H Svennerstam (2019). Nitrogen utilization during germination of somatic embryos of Norway spruce: revealing the importance of supplied glutamine for nitrogen metabolism. Trees 33(2), 383-394.

Cueva Agila AY, I Guachizaca \& R Cella (2015). Combination of 2,4-D and stress improves indirect somatic embryogenesis in Cattleya maxima Lindl. Plant Biosyst 149(2), 235-241.

El Dawayati MM, OH Abd El Bar, ZE Zaid \& AFM Zein El Din (2012). In vitro morphohistological studies of newly developed embryos from abnormal malformed embryos of date palm cv. Gundila under desiccation effect of polyethelyne glycol treatments. Ann Agric Sci 57(2), 117-128.

Emoghene B, O Asemota, C Eke, M Idu, E Aghimien \& A Nwite (2018). Evaluation of optimum concentration of naphthalene acetic acid on in vitro rooting and acclimatization of tissue culture date palm (Phoenix dactylifera L.) plantlets. J Appl Sci Environ Manage 22(10), 1595-1598.

Fki L, R Masmoudi, W Kriaa, A Mahjoub, B Sghaier, R Mzid, A Mliki, A Rival \& N Drira (2011a). Date palm micropropagation via somatic embryogenesis. In: Al-Khayri JM, DV Johnson, \& SM Jain (eds.), Date Palm Biotechnology. Dordrecht, Pays-Bas, Springer. p. 47-68.

Fki L, N Bouaziz, W Kriaa, R BenjemaaMasmoudi, R Gargouri-Bouzid, A Rival \& N Drira (2011b). Multiple bud cultures of 'Barhee' date palm (Phoenix dactylifera) and physiological status of regenerated plants.

Georgiev V, A Schumann, A Pavlov \& T Bley (2014). Temporary immersion systems in plant biotechnology. Eng Life Sci 14(6), 607-621.

Gurra-Downs (2019). Field trial date palms. Adelaide, Gurra Downs Date Company Pty Ltd.

Hassan MM \& RA Taha (2012). Callogenesis, somatic embryogenesis and regeneration of date palm Phoenix dactylifera L. cultivars affected by carbohydrate sources. Int J Agric Res 7(5), 231-242.
Hassan MM, IA Ibrahim, NM Fathy, MKH Ebrahim \& E Komor (2014). Protocol for micropropagated date palm acclimatization: Effect of micropropagated plantlet type, soil composition, and acclimatization season. Int $J$ Fruit Sci 14(2), 225-233.

Heringer AS, T Barroso, AF Macedo, C SantaCatarina, GHMF Souza, EIS Floh, GA de Souza-Filho \& V Silveira (2015). Label-Free quantitative proteomics of embryogenic and non-embryogenic callus during sugarcane somatic embryogenesis. PLOS ONE 10(6), e0127803.

Krishnan SS \& E Siril (2017). Auxin and nutritional stress coupled somatic embryogenesis in Oldenlandia umbellata L. Physiol Molec Biol Plants 23(2), 471-475.

Navarro BV, P Elbl, AP De Souza, V Jardim, LF de Oliveira, AF Macedo, ALW dos Santos, MS Buckeridge \& EIS Floh (2017). Carbohydratemediated responses during zygotic and early somatic embryogenesis in the endangered conifer, Araucaria angustifolia. PLOS ONE 12(7), e0180051.

Nic-Can GI, JR Avilez-Montalvo, RN AvilesMontalvo, RE Márquez-López, E MelladoMojica, RM Galaz-Ávalos \& VM LoyolaVargas (2016). The relationship between stress and somatic embryogenesis. In: Loyola-Vargas VM \& N Ochoa-Alejo (eds.), Somatic Embryogenesis: Fundamental Aspects and Applications. Springer, p. 151-170.

Oliveira EJ, AD Koehler, DI Rocha, LM Vieira, MVM Pinheiro, EM de Matos, ACF da Cruz, TCR da Silva, FAO Tanaka, FTS Nogueira \& WC Otoni (2017). Morpho-histological, histochemical, and molecular evidences related to cellular reprogramming during somatic embryogenesis of the model grass. Brachypodium distachyon. Protoplasma 254(5), 2017-2034.

Othmani A, C Bayoudh, N Drira \& M Trifi (2009). In vitro cloning of date palm Phoenix dactylifera L. cv. Deglet Bey by using embryogenic suspension and temporary immersion bioreactor (TIB). Biotechnol Biotechnol Equip 23(2), 1181-1188.

Othmani A, C Bayoudh, A Sellemi \& N Drira (2017). Temporary immersion system for date palm micropropagation. In: Al-Khayri JM, SM Jain \& DV Johnson (eds.), Date Palm Biotechnology Protocols Volume I: Tissue Culture Applications. New York, Springer New York. p. 239-249.

Parrilla J, C Gaillard, J Verbeke, M Maucourt, RA Aleksandrov, F Thibault, P Fleurat-Lessard, Y Gibon, D Rolin \& R Atanassova (2018). Comparative metabolomics and glycolysis 
enzyme profiling of embryogenic and nonembryogenic grape cells. FEBS Open Bio 8(5), 784-798.

Passamani LZ, AA Bertolazi, AC Ramos, C SantaCatarina, JJ Thelen \& V Silveira (2018). Embryogenic competence acquisition in sugar cane callus is associated with differential H+Pump abundance and activity. $J$ Proteome Res 17(8), 2767-2779.

Rahmadani RA, S Bulkis \& MA Budiman (2017). Potensi budidaya kurma di Indonesia ditinjau dari perspektif ekonomis dan ekologis. In: Prosiding Seminar Nasional ASBIS. Politeknik Negeri Banjarmasin, Banjarmasin p, 427-437.

Salo HM, T Sarjala, A Jokela, H Häggman \& J Vuosku (2016). Moderate stress responses and specific changes in polyamine metabolism characterize Scots pine somatic embryogenesis. Tree Physiol 36(3), 392-402.

Saptari, RT \& Sumaryono (2018). Embriogenesis somatik dari pucuk tunas tanaman kurma
(Phoenix dactylifera L.). Menara Perkebunan 86(2), 81-90.

Silveira V, AM de Vita, AF Macedo, MFR Dias, EIS Floh \& C Santa-Catarina (2013). Morphological and polyamine content changes in embryogenic and non-embryogenic callus of sugarcane. Plant Cell Tiss Org Cult 114(3), 351-364.

Sumaryono, I Riyadi, P Kasi \& G Ginting (2008). Growth and differentiation of embryogenic callus and somatic embryos of oil palm (Elaeis guineensis Jacq.) in temporary immersion system. Indonesian J Agric 1(2), 109-114.

Vidal N \& C Sánchez (2019). Use of bioreactor systems in the propagation of forest trees. Eng Life Sci 19(12), 896-915.

Watt MP (2012). The status of temporary immersion system (TIS) technology for plant micropropagation. Afr J Biotechnol 11(76), 14025-14035. 